\title{
Practice of Corporate Social Responsibility in Nepal
}

\author{
Dr. Manoj Kumar Chaudhary \\ Lecturer \\ Central Department of Management, \\ Faculty of Management, \\ Tribhuvan University, Kirtipur, Kathmandu, Nepal.
}

\begin{tabular}{|l|l|}
\hline Article History & $\begin{array}{l}\text { ABSTRACT } \\
\text { Article Submission } \\
\text { 11 September } 2017 \\
\text { Revised Submission } \\
29 \text { October } 2017 \\
\text { Article Accepted } \\
16 \text { November } 2017 \\
\text { Article Published }\end{array}$ \\
31 December 2017 & $\begin{array}{l}\text { to test the the CSR practice, the data have been collected from structured } \\
\text { questionnaire for descriptive analysis. Besides this, expert's opinion is also } \\
\text { observed to diagnose CSR mandatory issue in a real Nepalese perspective. } \\
\text { Therefore, the result of the study appears that government role has not been } \\
\text { effective to maintain its policy on CSR. So that, legal and ethical domains of } \\
\text { CSR are found to be poor in practice of Nepalese business society. } \\
\text { Furthermore, diverse views of experts found on CSR mandatory issues in Nepal. } \\
\text { Hence, it can be conclude that, it is not enough to just a making CSR policy } \\
\text { mandatory. However, along with policy, CSR has to be accountable and } \\
\text { transparent which shows their fund allocation and observed sectors. } \\
\text { Key Words: Corporate Social Responsibility, Practice, Problems, } \\
\text { professionals, Nepalese perspectives. }\end{array}$ \\
\hline
\end{tabular}

\section{INTRODUCTION}

Corporate social responsibility, since its emergence as a business idea in the 1960s, is understood as a business practice being responsive to societal needs. CSR makes it imperative upon a business organization to move away from its fixation on profit towards societal welfare.

There are three standard examples of CSR practice:, ethical, altruistic and strategic. Lantis, (2002) suggests that ethical CSR comprises of at least a minimum level of responsibility towards society-a conscientiousness that makes companies eschew initiating such activities which may be harmful to the society, even though the initiations may not be legal infringements. Next is altruism which corresponds with Carroll's (1997), recreational/volunteer responsibility which fuels the intent to contribute to the betterment of stakeholders, even if the cost of these activities may mean forfeiting company profit. Finally, strategic CSR intended as a tactic to improve corporate image along with securing employee's commitment and satisfaction besides boosting the confidence of the suppliers and retailers $n$.

- CSR practice is basically concerned with organizational growth, stakeholder benefit, organized way of operation, and respect for ethical, social and environmental sensitivities.

- According to Kotler and Lee (2005), CSR is an organizational pledge to advance community welfare on a voluntary basis through contribution of available corporate resources. Further the authors found an increased commitment on the part of some companies towards social well-being as it helped them build reputation and enhance brand image. 
CSR needs to be looked also from the perspective of business stakeholders which comprise of both shareholders and non-shareholder interests. Combined into one, business stake-holding interest groups consist of five categories such as investors, outside creditors, employees, consumers and the public. The latter two - the non-shareholding interest groups-which go unrepresented in the business governing body get addressed through CSR. Most of the literature on perception of CSR is either conceptual or based on the empirical research done on business managers (Quazi and O'Brien, 2000; and Singh et al., 1980, etc.) or the consumers (Sen and Bhattacharyam, 2001; Brown and Dacin, 1997; and Ellen, Mohr and Webb, 2000, etc.). These contentions indicate that there is a clear-cut link between an organization's CSR activity and its societal image. As P. Baral (2011) rightly contends, an organization's CSR report card enhances its image in the public mind, thereby aggrandizing its competitive thrust. Therefore, this intervention posits that an enviable CSR record affords a business organization the much-needed competitive thrust that it needs to survive the cut-throat competition. As R. E. Freeman argues, a firm fixated on profit alone, has a low societal image which makes it to vulnerable to stiff competitions

When a country has attained a sufficiently high standard of living, environmental legislation is passed, institutions for the protection of the environment are installed, compliance enforced. All these measures improve the health of the environment.. A corporation investing in more long-term strategies social responsibility practice becomes a more useful tool for sustainability and growth. Similarly, CSR is not merely an obligation of business enterprises towards the stakeholders but more importantly an opportunity for economic benefit and sustainable growth (Chapagain, 2012). Moreover, CSR practices of an organization have significant impacts on its reputation and performance (Sethi, et. al, 2011) Furthermore, societal perception of CSR has not caught the critical attention of Nepali researchers who can conceptualize CSR issues in Nepalese settings in several ways. Among these, Carrolls (1979) identified four tires (economic, legal, ethical and discretionary expectations) of responsibilities. However, in developing countries like Nepal, economic responsibilities followed by philanthropy still get the most emphasis than in the developed countries (Visser, 2005). Visser further claims that legal and ethical responsibilities in developing countries generally have a lower emphasis than in the developed countries. Therefore, there is less availability in Nepal of research work in the context of societal perception towards CSR practice by Nepalese firms.

Therefore, based on the literature it could be observed that a CSR practice in an organization is an essential tool and strategy that can impact on their operating environment and has meaningful consequences for their survival growth and performance. However, in Nepal there is under par research based on first hand information. Thus, so far as CSR practice in the Nepalese context is concerned, this study to some extent plugs this gap.

\section{CSR ISSUES IN NEPALESE CONTEXT}

The issues related to CSR in developing countries including Nepal have a structure that is based on the ideas distilled into the millennium development goals includes a world with less poverty and disease, healthy mother and their children, education for all, women empowerment healthier and sustainable environment and so on (UN, 2006). However, these aspirations remain ambitious for a country like Nepal which is underdeveloped. So, the major concern in this regard is: is CSR doing good to business and society? What is the role of Business Corporation in realizing the issue like millennium development goals of the country. Therefore, clarifying CSR contexts of Nepal is a worthwhile effort.

Developing countries still execute business, to a large extent, in terms of the lack of transparency, bureaucratic hurdles and corruption (The World Bank, 2005). Further in developing countries, legal and ethical responsibilities seem to have a lower priority (Visser, 2005b \& Reed, 2002). In recent years, Nepalese organizations have received a lot of flak with regard to CSR and good governance (Chaudhary, 2016). With liberalized economy and globalized financial market, the current CSR practice of the Nepalese 
firms needs to pick up. In this regard, the state should be a significant driver of CSR.

Awareness of CSR practice has grown in some selected Nepalese companies out to protect their familybrand image. It also appears that companies still have to go a long way towards focusing on both the inside and the outside of CSR agenda Once companies maintain CSR activities inside, they can come outside with CSR agenda in helping people in our society that may help raise their brand image, competitiveness and profits (Adhikari, et. al, 2016). Here it must be kept in mind that many private companies in Nepal are following a family style of management, which means that entrepreneurs run their business in their own way-mostly for pecuniary profit and family name.

According to Wetzel (2006), Nepalese companies can be divided into two clusters in terms of CSR situation. The first cluster of companies respects employee rights, such as written appointments for jobs, regular working hours and safety measurement. Such companies are connected to Indian companies or are the part of supply chains reaching out to Europe. A second cluster of companies are the small or mid-sized, familyowned business. The majority of them belong to private sector, and their activities are driven by the owners' convictions and interests rather than by international standards. The potential for business and societal benefits thorough CSR are not fully realized in these companies (Adhikari, et. al, 2016).

Another study jointly done by Upadhyay and Dhungel (2013) on 14 public and private commercial and development banks indicates that only 71 per cent of them are reporting about their CSR activities. According to this study, most of the CSR activities in which these banks are involved are related to education and training; welfare to the underprivileged, arts/and cultural protection; contribution to associations, clubs and other organizations; contributions for health care; and environment and so forth. Their study also reveals that CSR priorities on women empowerment and rural development are not high priorities of Nepalese business houses.

Furthermore, according Chaudhary (2016), social pressure and consumer groups are not found as strong as their counterparts are in some other developed countries. As a result, CSR movement is still in infancy stage. Therefore, the growth of CSR is required to link with the growth of consumers' beneficiary in Nepalese settings. Chaudhary, further claims that state's role and the roles of NGO and INGO have been found to enhance CSR activities in Nepal. It is heartening that in recent years, quite a few of the business firms in Nepal have incorporated CSR in their business practice. The attention towards social obligation has made them amenable to sacrificing their minimum level of profit for societal welfare (Sharma, 2016). Therefore, it can be discerned that the real involvement of Nepalese business community in CSR activities is still not clear. However, the concept of CSR is emerging in Nepal with the different motives. Thus, there are very few researches related to CSR practice in Nepalese context based on Carroll Model (1997). So, in this study this researcher seeks to explore CSR activities in Nepalese settings.

\section{CSR SHOULD MAKE IT MANDATORY OR NOT?}

At present, it can be said that CSR has been studied over decades and it has received a large amount of attention from the people, organizations and governments around the globe. Because CSR has become a high priority worldwide, shouldn't CSR be made mandatory? In this regard some scholars assert that CSR initiatives should be made mandatory by law to make business more responsible toward society while some other scholars think as the move to make CSR a legal compulsion is unnecessary (Sharma, 2016). Robin (2008) pointed out that CSR should be popularized but not be imposed. Whether the state has to use its power to make it mandatory nor not, quite a few organizations take CSR as a burden (Agrawal, 2015).

All over the world, every nation has its own way to encourage CSR practice. Great Britain has a minister for CSR, who is an expert of company law so that environmental and social performance may be effectively monitored (Douglas, et. al., 2004). However, in America, this kind of monitoring is not in practice because there the organizations themselves police the implementation of CSR which they project to the public 
through external communications. The system works well in America because of the long tradition of the involvement of corporate in social benevolence. Unlike America, Denmark toes more or less British line (Kampf, 2007). In Malaysia, all publicly listed companies are required to disclose their CSR activities in their annual reports. CSR disclosure, however, remains voluntary (Othman, 2011). In India, the amendment of the Companies Act in 2013 sparked debate as the Act mandated companies to spend at least two percent of their average net profit in CSR activities. However, in India, the practice of CSR is at an early phase as there is no mandatory rule to report CSR to all. In China, creating more and more employment opportunities is regarded as the main dimension of CSR (Xu and Yang, 2010). The Central Government adopted circular economy policy as an official development strategy in 2002, aiming to protect environmental degradation and resource scarcity issues due to poor industrial practices. Indeed, in China, members of the general public may not even be aware of a company's CSR initiatives. For this reason, many CSR programmes dovetail with the priorities of the local or provincial governments, such as education, health care and environment protection (Mullich, 2011). As in India, the Nepal government has also introduced a provision in the recently amended Industrial Enterprises Act which requires companies to spend at least one percent of their net profit for social initiatives. Earlier, Nepal Rastra Bank in the Monetary Policy for FY 2016/17 also asked banks to spend at least one percent of their profit in CSR activities (Sharma, 2016).

\section{RESEARCH METHODOLOGY}

The method of study has been classified into two parts: descriptive and exploratory. For descriptive research design, primary data were collected through the survey approach by distributing questionnaire personally. A judgmental sampling method was used to collect data from the faculty members of Central Departments of Management, Economics and Law at Central Campus, Tribhuvan University, Kathmandu, Nepal. Basically, those faculty members who are involved in teaching profession for at least 5 years and above. Altogether 160, 5-point likert-type scale questionnaires were distributed among them, but only 148, questionnaires were received. Among 148, 6 questionnaires were excluded due to them being incomplete. Therefore, 142 valid questionnaires were used in this study to apply Carroll's CSR Model (1997) to the Nepalese context in order to know the real scenario.

Besides, this study was carried out taking into consideration whether CSR should mandatory or not? In this paper among 76 experts from different backgrounds were called to participate in the focus group discussion on whether or not CSR should be made mandatory in Nepal since Nepal is still lea taken as an underdeveloped country. Statements of sixteen participants of the focus group discussion will be presented verbatim, and this researcher believes that the outcome of the discussion will be helpful regarding the final decision whether CSR in Nepal should be made mandatory or not..

\section{ANALYSIS OF RESULT}

This part of the research presents the acquired data in tabular form which simplifies the analysis process for easy comprehension. In this perceptual analysis of data, the following part presents dimension of CSR related to organizational benefit based on its adoption with CSR measures.

Table 1: Main Benefits of Adopting CSR

\begin{tabular}{|l|c|c|c|c|}
\hline \multicolumn{1}{|c|}{ Main Benefits } & N & Mean & $\begin{array}{c}\text { Std. } \\
\text { Deviation }\end{array}$ & Rank \\
\hline Rank enhancing corporate reputation & 142 & 2.09 & 1.355 & 1 \\
\hline $\begin{array}{l}\text { Rank improve relation with employees, institution and } \\
\text { community }\end{array}$ & 142 & 2.33 & 1.457 & 2 \\
\hline Rank efficiency increment & 142 & 3.91 & 1.626 & 3 \\
\hline
\end{tabular}




\begin{tabular}{|l|c|c|c|c|}
\hline Rank acquisition of commercial benefits & 142 & 3.65 & 1.226 & 4 \\
\hline Rank identification of reputational risks & 142 & 4.48 & 1.41 & 5 \\
\hline
\end{tabular}

For ranking, respondents are asked to rank the most important events 1 and accordingly for the main benefits of the adoption of measures of CSR. On the basis of mean analysis in the above table, what comes to the fore is that the respondents give most priority to enhancing corporate reputation and then improving relation with employees, institution and community. Likewise, they rank efficiency increment, acquisition of commercial benefits and identification of reputational risks as third, fourth and fifth important benefits in the adoption of CSR activities in the organization.

Table 2: Descriptive Statistics

\begin{tabular}{|l|c|c|c|}
\hline & N & Mean & Std. Deviation \\
\hline Economic & 142 & 3.11 & 0.277 \\
\hline Legal & 142 & 3.02 & 0.436 \\
\hline Philanthropic & 142 & 3.05 & 0.434 \\
\hline Ethical & 142 & 2.79 & 0.347 \\
\hline Growth & 142 & 2.94 & 0.369 \\
\hline
\end{tabular}

Based on the perception of academicians towards CSR dimension, what is revealed is that economic dimensions have received high attention followed by philanthropy in the Nepalese context.

Besides the above empirical analysis, 76 experts from different background like academicians, lawyers, industrialists, bankers, entrepreneurs and member of Federation of Nepalese Chambers of Commerce and Industry (FNCCI) were invited to participate in the focused group discussion on CSR mandatory issues. Among them 16 concrete statements were collected. These are presented below:

Statement 1: I strongly feel that CSR should be made mandatory. Business makes profit from the society. So, it is ethical that they should give back to the society. Also, it is evident from the history that majority of the companies are not proactive in engaging in CSR activities and that they should try to find ways out to invest in social development. Once it is made mandatory, we can see significant funds available to be invested in social welfare.

Statement 2: CSR should be made mandatory because business flourishes through society. Investing in philanthropy is like disposing garbage in the middle of the river which is ultimately going to come back to the ones who threw it there.

Statement 3: CSR should be voluntary and not mandatory because businesses themselves have started realizing that they are nothing without society. If they can stand for the society when in need, the society will definitely reciprocate.

Statement 4: If it is imposed under legislation, it is a legal responsibility and not a social responsibility. The road for CSR begins right from the dead-end of law. To earmark the extra spending should be up to the choice of corporate themselves.

Statement 5: Well, we are high taxpayers and have been contributing to several aspects. For example, we have been spending on donation, levy, charity, etc. Likewise, we have created employment opportunities in the service sector, even though no facilities and concession are provided to us. Besides government depends on us for the development of the economy. So, having proactive involvement in all socio-economic aspects I think, it should be considered as the part of CSR. Therefore, it should not be mandatory at this juncture. 
Moreover, we believe in karmayog.

Satement 6: Jurisprudentially, CSR is a part of social contract theory. This theory views that every human's moral and/or political obligations are dependent upon a contract or agreement to form the society in which they live. Though the corporate bodies are incorporated for the business motive, meantime, they should be ethically obliged to contribute something to the society in which they exist, grow and gain from there. Hence, to legally execute this concept and to make harmonious relation between corporate bodies and the society, most of the modern nations enforce the corporate body to fulfill the corporate social responsibilities as the statutory obligations and I think it should be made mandatory.

Statement 7: Nothing should be mandatory, but all actions of not only social corporate also everyone needs to emerge from the depths of one's heart. Responsibility is the ability to RESPOND to what is needed here and now. Ability to take conscious actions consistent to one's value/organizational values, goals is need of the hour. But how can anybody think of making anyone RESPONSIBLE mandatorily or by FORCE?

Statement 8: CSR should be mandatory and transparent in the case of least developed and developing countries. Business organizations earn profit from the society. Therefore, they have to spend some portion of the earned profit to the society. It is not enough just making the CSR activity mandatory, but it has to be transparent to find out whether the CSR fund is being properly utilized or not. It has to be regulated in a transparent way to find out whether the deserving stakeholder actually gets the benefit or not. In the context of Nepal, Nepalese banks have to allocate 1 percent. But, some banks are using that allocated fund for the education of the staff's children. The CSR fund should be beneficial to all stakeholders-not just staff of the organization. In the case of developed countries, CSR should be voluntary and transparent. The government should give tax exemptions for CSR fund in all the countries.

Statement 9: I don't believe that CSR should be mandatory. Business firms will simply consider CSR as part of their regular compliance. Government can do nothing, except to require industries to allocate certain percentages of profit for CSR. I doubt if such allocation will create any social or environmental impact. Further, government will be able to mandate each and every policies and programmes of CSR. CSR are now promoted by business firm as their business strategy. Business houses are designing their programme focusing on their business needs and competencies. I believe, it will provide them sufficient scope to create some social and environmental impact simultaneously providing some business gain to them as well.

However, CSR can be made a part of regulation. Broad policies may define certain requirements on business firms on consumer protection, environmental protection, and price stabilization. These things can be checked and regulated. However government cannot mandate the firms in their philanthropic responsibilities. This will ultimately limit the firm itself in implementing CSR activities.

Statement 10: The business themselves need to come upfront realizing their responsibilities towards the society. Forceful CSRs cannot be fruitful and achieve intended results. Further, I believe that CSR is basically guided and motivated by the feelings and sentiments of individuals or group for social welfare and good causes. Though it is a good thing to get engaged in philanthropy, its long term impact is limited. Therefore, CSR is done in several ways by evaluating the impact of such activities for the targeted communities alongside the business themselves which are engaged. Recently, the business community in Nepal has been contributing to many social welfare programmes.

Statement 11: The NRB initiative is really appreciable, if I have to give my personal opinion on it. The CSR activities indirectly pay back to all the stakeholders - owners, investors, employees, customers, government, etc. CSR is also responsibility of all corporate entities whether they are for profit or not for profit. Concluding my view on mandatory framework of CSR fund, I do support on NRB directive in this regard. 
Statement 12: No, it may not be practicable for all. Even though, it has certain level of benefits to the people.

Statement 13: Yes, it is helpful for branding, increase awareness, enlarge impression, positive view to the people. We (NIC ASIA) have Foundation which has been serving in the rural areas in the form of providing child health facilities, girls' education in remote areas and contributions to earthquake rehabilitation fund.

Statement 14: Yes, it should be mandatory because organization has responsibility to the society. So, welfare of the people is the must.

Statement 15: Not mandatory, because quality service cannot guarantee through the corporate social responsibility. But, organization can voluntarily put its efforts to donate for or to contribute to the people's welfare.

Statement 16: It should be mandatory because organization's portion of profit also should be focused on human welfare.

\section{CONCLUSION AND IMPLICATION}

The result in Table 1 indicates that the respondents of this study tend to mostly agree that an adoption of CSR practice will enhance business image which will at the same time improve organizational growth and profitability. It also appears that Nepalese business communities have realized the importance of CSR not only as a benefit to business and the investor but also as a factor in harmonizing the relationship among employees, investors, consumers and the community to which they belong. Therefore, it can be concluded that CSR domains can be mostly influenced by the contextual as well as external factors. Thus, for competitiveness Nepalese business bodies are required to adopt interested CSR practice as an organizational strategy in relation to create a positive environment to beneficial to both the business and the society in the long run.

Similarly, the result from Table 2 shows that the economic domains followed by philanthropic activities of CSR are more predominant than the legal and ethical domains of CSR in the Nepalese context. So, from the result, it can be inferred that the strategic economic motivation of CSR is increasing in Nepal. At present, philanthropy CSR is also found to be in a strong position in Nepal. However, it is a must for Nepalese business to pay attention towards making the stakeholders happy for a smooth functioning. Besides this, legal and ethical domains of CSR are found to be in poor shape in the Nepalese context. What this means is that government role has not been effective in maintaining its policy act which is formulated by government itself. In regard to this, in Nepal, the Companies Act, 2063, Section 105 (1) (c) states that while making a contribution, donation or gift in a sum exceeding fifty thousand rupees in one financial year or a sum exceeding one per cent of the average net profits of the company during the last three financial years, whichever is the lesser, except the contribution, donation, gift etc. made for the welfare of its employees or for the promotion of its business.

Therefore, to theorize the findings, the act and policy are formulated by the government about CSR but the government role of CSR to support and maintain at all level is found to be less effective. Thus, proper plan, programme and their implementation mechanism should be streamlined by the government initiatives and then the public and private sectors should be regulated strategically.

To glean from the group discussion outcome, it seems that there is a disagreement. In this regard, on the one hand it is found that most of the people are against making CSR mandatory, on the other hand they seem to be responsive to government policy implementation, greater transparency and accountability in the discharging of CSR activities. Based on the debate, it has been noticed that CSR is basically guided by the feelings and sentiments of business society for social welfare. CSR comprises of three elements such as government, business and society, so a positive or negative development on the part of any one of them will 
affect all three of them. Therefore, it can be concluded that in Nepal, explicit framework for CSR implementation is required rather than a superimposition.

An analysis of the statements by the advocates for making CSR mandatory reveals that that since Nepal is still considered as an under-developed country in terms of per capita income, infrastructure, development, industrial growth, gross domestic product education, less capital formation, unemployment, and the like, so CSR should be enforced compulsorily. Its need becomes even more pressing, given the fact that Nepal is passing through a transitional phase when a lot of things are not functioning in a systematic way. Obviously, the legal and ethical domains of CSR are in weak position in Nepal. Therefore, in order to achieve competitiveness of the Nepalese business society in the global context, it is an essential that CSR be made mandatory in order to improve, healthier business environment, support millennium development goals of the country and contribute to the society's overall welfare. Thus, based on the outcomes of the debate, the study concludes that in Nepal It is not enough to just make CSR mandatory. Along with the stress on the obligatory, what is equally needed is making the CSR practice accountable and transparent. The bottom-line is that the CSR fund should be utilized tellingly.

At all levels respondents show an awareness of and positive expectation towards CSR activities in Nepal. Further, it appears that the concept of CSR is emerging in Nepal and is inflected with the different motives of the companies. Therefore, the growth of CSR is required to be linked with the growth of consumerism. In addition, state role at all levels to maintain and strengthen the CSR activities is a crying need. Moreover, legal and ethical domains are of CSR are quite low in the Nepalese context, so a new CSR strategy and its practice are required for building awareness among business houses, general people as well as governmental bodies. Finally, the way forward for all academicians, business community, and government are to embrace CSR in more innovative and strategic ways.

\section{REFERENCE}

[1]. Adhikar, D.R.; Gautam D.K. and Chaudhari, M.K. (2016). 'Corporate Social Responsibility domains and related activities in Nepalese Companies', International Journal of Law and Management, 58(8), 673-684.

[2]. Agrawal, G.R. (2015). Business Environment in Nepal. M.K. Publishers \& Distributors, Bhotahity, Kathmandu, Nepal.

[3]. Baral, P. (2011): Managerial Intensity towards CSR: A Survey among Nepalese Managers. The Lumbini Journal of Business and Economics, Vol II.

[4]. Carroll, A.B. (1997), "A three-dimensional conceptual model of corporate performance". Academy of Management Review, 4 (4), 497-505.

[5]. Chapagain, B.R. (2013). 'Corporate Social responsibility in financial service and manufacturing sectors of Nepal'. Unpublishede M.Phil thesis, Tribhuvan University, Kathmandu.

[6]. Chaudhary, M.K. (2016). 'A case study on Societal Perception of Corporate Social Responsibility in Nepal'. BIMTECH, Greater Noida, New Delhi, India.

[7]. Douglas A.; Doris, J.; \& Johnson, B. (2004). Corporate social reporting in Irish financial institutions. The TQM Magazine, 16 (6),387-395.

[8]. European Commission (2011). Communication from the Commission to the European Parliament, The Council, the European Economic and Social Committee and the Committee and the Committee of the Region: A Renewed EU Strategy 2011-14 for Corporate Responsibility, European Commission, Brussels.

[9]. Kampf, C. (2007). CSR WalMart, Maersk and the cultural bounds of representation in corporate web sites. Corporate Communications: An International Journal, 12 (1), 41-57.

[10]. Lantos, G.P. (2002). The ethicality of altruistic CSR. Journal of Consumer Marketing. 19 (3), 205230 
[11]. Mullich, J. (2011). 'Corporate Social responsibility emerges in China', available at: http://online.wsj.com/ad/article/chinaenergy-responsibility

[12]. Othman, S.; Darus, F.; and Arshad, R. (2011). The influence of coercive isomorphism on corporate social responsibility reporting and reputation. Social Responsibility Journal, 7 (1), 118135.

[13]. Quazi, A.M. and O'Brien, D. (2000). An Empirical Test of Cross-National Model of Corporate Social Responsibility. Journal of Business Ethics, 25, 33-51.

[14]. Robin, F. (2008). Why Corporate social responsibility should be popularised but not imposed. Corporate Governance, 8 (3), 330-341.

[15]. Sethi, S.P. (1975). Dimensions of corporate social performance: an analytical framework. California Management Review, 17 (3), 58-64.

[16]. Sharma, N. (2011). Corporate social responsibility Practices and Corporate social responsibility Reporting in Indian Banking Sector. International Journal of advanced economics and business management, 1 (2), 58-66.

[17]. Sharma, S. (2016). 'CSR: How doing good for Society is Good for business'. New Business Age, $16(3), 57-71$.

[18]. The World Bank's (2012). Migration and Remittance Fact book 2011, World Business Council for Sustainable Developmen.

[19]. UN (2006). Millennium Development Goals Report 2006. Brussels: United Nations.

[20]. Upadhyay, K. and Dhungel, A. (2013). 'Corporate Social Responsibility reporting practices in the Banking Sector of Nepal', Banking Journal, 3 (2), 61-78.

[21]. Venkataratnam, C.S., Sankaran, K. and Somayajulu, G. (2009). 'Corporate Social responsibility - a note'. paper presented at the International Seminar on the Status of Corporate Social Responsibility, Mahatman Gandhi Labour Institute and Friedrich Ebert Stiftung, Ahmadabad, 1213 November.

[22]. Visser, W. (2005a). 'Corporate Citizenship in South Africa: A Review of Progress Since Democracy'. Journal of Corporate Citizenship, 18, summer: 29-38.

[23]. Welzel, C. (2006). Corporate social responsibility in Nepal: A Chance for Peace and Prosperity? Report based upon a Mission to Nepal.

[24]. Welzel, C. (2006). Corporate Social Responsibility in Nepal: A Chance for Peace and Prosperity? Report based upon a Mission to Nepal in November 2006.

[25]. Wood, D.J. (1991). Corporate social performance revisited. Academy of Management Review, 16 (4), 691-718.

[26]. Xu, S. and Yang, R. (2010). 'Indigenous Characteristics of Chinese Corporate Social Responsibility conceptual paradigm', Journal of Business Ethics, 93, 321-333. 